\title{
PENDIDIKAN BERKARAKTER ISLAMI BAGI ANAK YATIM
}

\author{
Ririn Purwigati Wahyuningtyas \\ Institut Pesantren Kh Abdul Chalim Mojokerto \\ Ririnpwn07@gamil.com \\ Ismatun Nihayah \\ Institut Pesantren Kh Abdul Chalim Mojokerto
}

\section{Pendahuluan}

Pendidkan merupakan hak setiap warga negara Indonesia, dengan ini pemerintah wajib menyediakan kesempatan yang sangat luas kepada rakyatnya supaya memperoleh pendidikan yang berkualitas.

Tercantum dalam pembukaan UUD 1945 alenia 4 yang menyatakan bahwa Negara bertujuan untuk mencerdaskan kehidupan bangsa. Dengan ini maka hak atas pendidikan berarti meatauntuk semuakalangan masyarakat baik yang kaymaupun yang miskin dan juga yang normal atau berkebutuhan khusus.

Anak yatim adalah salah satu diantara anak-anak yang memerlukan pendidikan dngan kurikulum kebutuhan khusus atau yang biasa di kenak dengan sebutan special need, ini dikaenakan anak yatim memang dari awal telah kehilangan sosok figur ayah yang sejatinya sebagai penganyomuntuk dirinya. Karena hal ini sehingga anak yatim memiliki karakter atau pembawaan yang berbeda dengan anak - anak pada umumnya. Dapat dilihat dari sini model penerapan pendidikan bagi mereka harus disesuaikan dengan kebutuhan mereka. Perlu di perhatikan bahwa penerapan stategi pembelajaran harus disesuaikan dengan kebutuhan peserta didik, seperti prinsipdi bawah ini:

1. Semakin kecil upaya yang di lakukan guru akan semakin besar aktivitas belajar peserta didik.

2. Emakin sedikit waktu yang diperlukan guru mengktifkan peserta didik akan semakin banyak waktu untuk belajar peserta didik.

3. Sesuai dengan cara belajar peserta didik.

4. Dapat di laksanakan dengan baik dilaksanakan dengan baik oleh guru.

Keberhasilan dari suatu proses belajar sangat ditentukan oleh kondisi komponen seperti tujuan, bahan, peralatan serta suasana tempat berlangsungnya proses belajar mengajar. Sehingga semua itu sudah di tentukan atau disusun dalam satu lingkup dilingkungan penidikan. Proses belajar dikatakan efektif ketika 80\% peserta didik mempau mencapai $80 \%$ dari tujuan pembelajaran, bukan hanya itu proses belajar dikatakan sukses atau berhasil ketika semakin sedikit tingkat kesalahan dari apayang sudah dilakukan. Dalam mencapai itu semua dibutuhkan suatu komponen yang berada dalam kondisi prima agar pendidikan bisa berlangsung dengan baik dan efektif. 
Kurikulum dan sistem pendidikan yang diterapkan pada suatu lingkungan pendidikan itu menentukan keefektifitasan suatu proses pembelajaran ${ }^{1}$, berhubungn dengan pendidikan untuk anak yatim maka diperlukan kurikulum khusus untuk menjawab dan memenuhi kebutuhan anak yatim baik kebutukan fisik maupun spiritual. Kebanyakan dijumpai di lembaga- lembaga pengasuhan anak yatim banyak menggunakan model pendidikan yang sama yang diterapkan pada anak - anak normal lainnya, padahal sebenarnya anak yatim sangat memerlukan pendidikan yang sangat khusus karena mereka itu berbeda dengan anak - anak normal pada umumnya, mereka adalah anak - anak yang kehilangan sosok figur seorang ayah. Emosi meraka cenderung tidak terkontrol kadang mudah marah, bersikap masa bodoh, kurang respek, merasa bebas dan terkadang kurang ada rasa hormat pada orng di sekitar mereka.

Sebenarnya yang dibutuhkan adalah adanya model pendidikan berkarakter islami untuk mengarhkan anak yatim membentuk kesiapannya dalam mental dan spiritual untuk menjadi manusia yang matang secara fisik dan mental. Dengan model seperti ini diharapkan anak yatim akan dapat melewati masa anak - anak mereka secara nornal guna menyiapkan diri menuju masa dewasa. Denganini maka sayaakan membahas sedikit tentang pendidikan berkarakter bagi anak yatim.

\section{Pembahasan}

\section{Pengertian pendidikan}

Banyak para ahli yang kesulitan dalm merumuskan definisi daripenidikan. kesulitan itu sendiri disebabkan oleh banyaknya kegiatan - kegiatan yang masing masing dari kegitan terebut bisa disebut dengan pendidikan. Dengan kata lain kesulitan tersebut disebabkan oleh banyaknya kegiatan - kegiatan yang haru dibina dalam pendidikan.

Dalam pengetian yang luas pendidikan itu menyangkut seluruh pengalaman. Dari mulai anak mendidik orang tuanya, murid menidik gurunya, sampai anjing mendidik tuannya. Semua yang kita sebut atau kita lakukan dapat disebut mendidik, begitu juga yang dikatakan dan dilakukan oleh selain kita dapat disebut mendidik kita. Dalam pengertian yang luas ini kehidupan adalah pendidikan dan pendidikan adalah kehupan itu.hal ini diungkapkn oleh Rupert C. Lodge dalam Philosophy of education. ${ }^{2}$

Pendidikan merupakan hak setiap warga Negara Indonesia, sehingga pemerintah harus menyediakan kesempatan seluas - luasnya kepada rakyatnya agar dapat memperoleh pendidikan yang berkualitas. Pada pembukaan UUD 1945 alinea 4 menyatakan bahwa Negara bertujuan mencerdaska kehidupan bangsa. ${ }^{3}$

${ }^{1}$ Muhammad Anas Ma’arif and Muhammad Husnur Rofiq, 'Pola Pengembangan Kurikulum Pendidikan Pesantren Berkarakter: Studi Pondok Pesantren Nurul Ummah Mojokerto', TADRIS: Jurnal Pendidikan Islam 13, no. 1 (7 September 2018): 1-16, https://doi.org/10.19105/tjpi.v13i1.1635; Yunus Abidin, Desain Sistem Pembelajaran Dalam Konteks Kurikulum 2013, Cetakan kesatu (Bandung: Refika Aditama, 2014).

2 Prof.Dr. ahmad Tafsir, Metodologi Pengajaran Agama Islam, ed. Mukhlis (bandung: PT Remaja Rosdakarya Offset, 2017).

${ }^{3}$ Oleh Abdurrahman et al., 'PENDIDIKAN BERKARAKTER ISLAMI BAGI ANAK YATIM Oleh: Abdurrahman Misno Bambang Prawiro* Abstrak', 2009. 
Selanjutnya diatur juga dalam pasal 31 ayat 1 UUD 1945 yang menyebutkan bahwa untuk mewujudkan tujuan tersebut, maka setiap warga Negara memiliki hak untuk mendapatkan pengajaran. Secara operasional, bentuk dukungan pendidikan yang terdapat dalam UU Nomor 20 tahun 2003 yang membahas tentang Sistem Pendidikan nasional pasal 5 yang menyatakan bahwa setiap warga Negara memiliki hak yang sama untuk memperoleh pendidikan yang bermutu. ${ }^{4}$

Bila pendididkan diartikan sebagai latihan mental, moral, dan fisik yang bisa menghasilkan manusia berbudaya tinggi maka pendidikan berarti sebagai bahan untuk menumbuhkan personalitas (kepribadian) serta menanamkan rasa tanggungjawab. Usaha kependidikan bagi manusia itu menyerupai makanan yang berfungsi memberikan vitamin bagi proses pertumbuhan manusia. ${ }^{5}$

Dari pengertian diatas dapat disimpulkan bahwa pendidikan adalah proses pengalaman karena kehidupan adalah suatu pertumbuhan, dengandemikian pertumbuhan dapat diartikan sebagai dorongan pertumbuhan batin tanpa adanya batas usia, proses pertumuhan juga dapat diartikan sebagai proses penyesuaian pada setiap fase yang akan dialaminya serta memberikan kecapan didalam perkembangan seseorang. Ada bebrapaalasan mengapa ilmu pendidikn sangat diperlukan, antara lain:

1. Pendidikan digunakan untuk usaha membentuk kepribadian manusia, halini diperlukan waktu yang sangat panjang, dan hasilnyatidak langsung diketahui segera. Dalam proses tersebut dibutuhkan suatu pemikiran - pemikiran atau teori yang tepat, sehingg kesalahandalan implementasinya dapat dihindari. Karena ketika salah dalam proses pembelajaran memperbaikinya tidak mudah.

2. Pendidikan islam yang bersumber dari niali- nilai ajarn islam harus bisa membentuk sikap dan kepribadian yang baik.oleh karena itu dalam pembentukan sikap ini tidak hanya berdaarkan pada trial and error (coba coba) atau hanya didasari oleh kemampuan pendidik tanpa dilandasi dengan teori-teori kependidikan yang nantinya dapat di pertanggungjawab kan secara ilmiah.

3. Ruang lingkup pendidikan islam mencakup beberapa bidang dalam kehidupan manusia di dunia, oleh karena itu dalampembentukan sikapdan nilai amaliyah keislaman dapat dibentuksecara efektif dengan proses pendidikan.

Oleh sebab itu, diihat dari segi teoritisnya pendidikan islam berarti suatu konsep berpikir yang sangat mendalam dan terperinci tentang suatu masalah yang berkaitan dengan pendidikan yang bersumber dari ajaran ilam muali dari rumusan - rumusan konsep dasar, pola, sistem, tujuan, materi, dan metode.

1. Pengertian anak yatim

Secara bahasa "yatim" berasal dari bahasa arab, yang merupakan bentuk dari suatu isim fa'il (subyek). Bentuk kata kerja lampau atau fi'il madhinya yaitu "yatama”, sedangkan kata kerja bentuk sekarang/akan datang atau disebut dengan mudhori' "yaitamu". Adapun bentuk mashdarnya "yatmu" yang berarti : sedih, kata yatmu

\footnotetext{
${ }^{4}$ Abdurrahman et al.

${ }^{5}$ M.Ed. prof. H.M. Arifin, Filsafat Pendidikan Islam, ed. Fauzan Asy (PT Bumi Aksara, 2016).
} 
bermakna pula "sendiri". Kata yatim itu juga bermakna anak binatang semisal sapi yang ditinggal mati induknya, atau terpisah darinya.

Menurut istilah syara' yang dimaksud dengan anak yatim adalah anak yang ditinggal mati oleh ayahnya sebelum dia baligh. Dalam Qamus Al-Munjid disebutkan bahwa yatim adalah annak kecil yang belum baligh yang ditinggal mati oleh atyahnya. Semua ahli bahasa telah sepakat bahwa anak yatim adalah setiap anak yang ayahnya meninggal ketika dia belum baligh. ${ }^{6}$

Anak yatim adalah anak yang sudah ditinggal mati oleh ayahnya sebelum dia baligh, dan batasan seorang anak dikatakan yatim adalah ketikadia sudah baligh dan dewasa. Didalam ajaran islam anak yatim mendapat perhatian khusus dibandingkan dengan anak - anak lainnya yang masih memeiliki kedua orang tua. Islam mengajarkan kita untuk memperhatikan mereka, berbuat baik kepada mereka mengurus dan mengasuh mereka serta menyayangi mereka. Islam juga begitu mengistimewakan mereka yang menjalankan perintah ini.

anak yatim dalam islam mendapat tempat yang begitu muliah halini di jelaskan dalam hadist

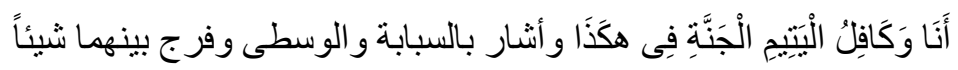

"Aku dan orang yang menanggung anak yatim (kedudukannya) di surga seperti ini”, kemudian beliau shallallahu 'alaihi wa sallam mengisyaratkan jari telunjuk dan jari tengah beliau shallallahu 'alaihi wa sallam, serta agak merenggangkan keduanya."

Ketikada seseorang yang mendidik anak yatim itu termasuk bentuk amal yang mulia bagidirinya, sedangkan menyia - nyiakan mereka adalah menjadi suatu bentuk dosa. Seperti dalam firman Allah:

\section{كلا بل لاتكرمن اليتيم}

Sekali - kali tidak (demikian), sebenarnya kamu tidak muliakan anak yatim. QS Al - fajr:17.

Ada beberapa bentuk tidak memuliahkan anak yatim diantaranya adalah dengan menyia - nyiakan mereka sehingga menjadikan kehidupan mereka menjadi kekurang dan akhirnya menderita. Ada juga bentuk dalam menyia - nyiakan anak yatim yaitu dengan cara tidak memberikan mereka model pendidikan yang tidak sesuai apa karakter dan kebutuhan mereka, dan model yang digunakan dalam proses mendidiknya itu menjadikan suatu beban baginya.

Larangan berbuat sewenang - wenang juga telah dijelaskan dalam islam, sepeti memakan hartanya dengan jalan haram, memberikan pendidikan yang menjadikan sebagai beban bagi mereka sehingga mereka tidak merasa nyaman, meskipun niatnya memberikan pendidikan namun justru pendidikan yang telah diterapkan membeni mereka,maka hal ini tidak diperbolehkan. Dalam islam telah diwajibkan pada seluruh umat memuliahkan mereka, diantara cara memuliahkan mereka kita sebagai guru bisa memuliahkan mereka dengan cara memberikan pendidikan yang sesuai atau selaras dengan kebutuhan merekadari mulai yang paling mendasar.

Ada beberapa kebutuhan dasar yang dibutuhkan oleh anak yatim yaitu:

${ }^{6}$ Abdurrahman et al., 'PENDIDIKAN BERKARAKTER ISLAMI BAGI ANAK YATIM Oleh: Abdurrahman Misno Bambang Prawiro* Abstrak'. 
1. Membutuhkan sosok figur ayah.

2. Membutuhkan pendidikan kemandirian.

3. Membutuhkan kehidupan yang cakap.

4. Membutuhkan pembinan agar siap mental dan spritual.

Maka dari itu mereka sangat membutuhkan pendidikan yang berakter islam untuk menunjang kebutuhan dasar mereka supaya mereka tetap menjadi anak - anak yang hidup seperti anak yang masih memiliki kedua orang tuanya sehingga mereka tidak lagi memiliki sikap minder atau tidan percaya diri dan tidak merasa ada perbedaan diantara mereka.

Banyak kita jumpai anak yatim dari mulai tingkat balita, Madrasah Ibtidaiyyah (MI), Madrasah Tsanawiyah (MTs), Madrasah Aliyah (MA), merakaini sangat membutuhkan kebutuhan khusus dari pada anak pada umumnya, kebanyakan tingkan kemandirian anak yatim lebih tinggi dari pada anak pada umumnya karena umumnya anak yatim itu terbiasa hidup sendiri, hanya saja tingkat emosi mereka saja yang cenderung tidak stabil.

\section{Pengertian karakter}

Bahwa karakter terbentuk dari pengaruh luar, terbentuk dari asimilasi dan sosialisasi. Asimilasi itu segala hal yang menyangkut hubungan manusia dengan lingkungan bendawi, sedangkan sosialisasi yaitu segala hal yang menyangkut hubungan antar manusia. Kedua unsur inilah yang membentuk karakter dan karakter merupakan pola seseorang berhubungan dengan lingkungannya menurut Jalaludin. ${ }^{7}$

Menurut Kepmendiknas, karakter adalah sikap seseorang sebagai nilai-nilai yang khas baik seperti tahu nilai kebaikan, mau berbuat baik, nyata berkehidupan baik, dan berdampak baik terhadap lingkungan, yang tertanam dalam diri dan diwujudkan dalam perilaku. Andrianto (2011:20) telah menjelaskan "karakter meliputi serangkaian sikap seperti keinginan untuk melakukan hal yang terbaik, kapasitas intelektual, seperti berpikir kritis dan alasan moral, perilaku seperti jujur dan bertanggung jawab, mempertahankan prinsip-prinsip moral dalam situasi ketidakadilan, kecakapan interpersonal dan emosional yang memungkinkan seseorang berinteraksi secara efektif dalam berbagai keadaan, dan komitmen untuk selalu berkontribusi dengan komunitas dan masyarakatnya".

Perkembangan karakter anak bangsa dapat dibentuk melalui karakter individu seseorng. Akan tetapi, karena manusia itu hidup sebagia makhluk sosial dan berbudaya, maka dalam pembentukan karakter individu dilakukan dalan lingkungan sosial dan budaya yang bersangkutan dengan linfkungan. Dapat diartikan pendidikan karakter manusia tidak pernah lepas dari lingkungn sosial, masyarakat, dan budaya bangsa.

Pendidikan tingkat dasar harunya menitikberatkan pada pembentukansikap yang baik dari pada ilmu pengetahuan lainnya. Karena dari pendidikan dasar ini berharap individu akan menciptakan peubahan menjadi individu yang lebih baik dalam kehidupan dan sebagai penunjang untuk pendidikan selanjutnya. Dalam pendidikan dasar ini sehausnya terbentuk fondasi yang kuat agar apa yang sudah terbentuk tidak akan goyah lagi. Karana ketika semakin tinggi ilmu yang di dapat maka semakin banyak pula ragam

\footnotetext{
7 Sri Haryati, ‘Pendidikan Karakter Dalam Kurikulum 2013', 2013, 1-21.

${ }^{8}$ Sri Haryati.
} 
ilmu yangdi dapatkan dan kemungkinan problem didapat pun juga besar jka fondasi itu hancur maka pendidikan karakter dasar pun akan runtuh.

Pendidikan karakter ini merukan suatu hal yang sangat penting yang harus dimiliki oleh setiap individu. Hal ini menjadikan pendidikan berkarakter itu sangat diperlkan oleh setiap individu karena merupakan alat terbesar yang menjamin kualitas hidup individu dan keberhasilan dalam bermasyarakat. Bukan hanya pendidikan formal yang dibutuhkan dalam pembentukan karakter tapi juga kemampuan memperbaiki diri dan pengalaman juga merupakan yang yang menunjang dalam pembentukan karkter seseorang dalam bermasyarakat. Disini dapat terlihat dengan jelas bahwa pendidikan karakter dasar sangat perting bagi setiap individu dalan menunjang kehidupan dan bermasyarakat yang baik?

Sesorang bisa dikatakan berkarakter yaitu ketika orang tersebut dapat menerima respon dengan bermoral, yang akan memunculkan perilaku atau tindakan yang baik. Dengan demikian karakter dapat diartikan sebagai nilai - nilai yang tertanam pada dirisendiri yang didapat dari pebdidikan dan pengalaman yang menjadi nilai dari dalam diri sendiri yang melandasi sikap dan perilaku seseorang.

Dari penjelasan diatas dapat disimpulkan bahwa karakter merupakan suatu usaha Untuk mengaplikasikan nilai -nilai, kebiasaan dan perilaku yang diwujudkan melalui tindakan dengan stabil, sesuai dengan kondisi lingkungan.

Proses pembentukan karakter individu sangat penting dan sangat membutuhkan waktu yang sangat lama dan berlangsung seumur hidup. Apalagi karakter itu sendiri tidak dibawah oleh individu sejak lahir,akan tetapi dibentuk oleh pengalaman - pengalaman yang di dapat selama hidupnya, hal ini yang akan merubah karakter seseorang.

Pendidikan karakter sendiri sangat membutuhkan peran dari semua pihak, seperti orang tua, sekolah, lingkungan sekolah, dan masyarakat luas. Oleh karen itu tingkat keberhasilan dalam pembentukan karakter dapat dilihat atau dinilai dari kerjaama, keseimbangan dan keharmonisan semua aspek tersebut. Pendidikan karakter sendiri sangat penting dalam lingkungan keluarga, karena banyak orangtua yang menginginkan anaknya mempunyaikarakter yang baik.

Walgito berpendapat bahwa pembentukan perilaku hingga menjadi karakter dapat menggunakan tiga cara yaitu: (1) kondisioning atau pembiasaan, dengan cara membiasakan diri untuk berperilaku seperti yang diharapkan, akhirnya akan terbentuklah perilaku tersebut, (2) pengertian (insight), cara ini mementingkan pengertian, dengan adanya pengertian akan perilaku maka akan terbentuklah perilaku, (3) model, dalam hal ini perilaku terbentuk karena adanya model atau teladan yang ditiru. Lebih di perdalam oleh Zuhriyah berpendapat bahwa dalam penanaman nilai dan pembentukan karakter dapat dibentuk melalui berbagai macam suasana sepeti, suasana belajar, suasana bermain, pembaiasan hidup baik dan teratur yang ada pada anak hendaklah lebih didukung dan

9 Muhammad Anas Ma'arif, 'Analisis Strategi Pendidikan Karakter Melalui Hukuman Preventif', Ta'allum: Jurnal Pendidikan Islam 6, no. 1 (6 March 2018): 31-56, https://doi.org/10.21274/taalum.2018.6.1.31-56; Muhammad Nur Hakim and Fitriyani Dwi Rahayu, 'Pembelajaran Saintifik Berbasis Pengembangan Karakter', Nazhruna: Jurnal Pendidikan Islam 2, no. 1 (24 February 2019): 1-27, https://doi.org/10.31538/nzh.v2i1.148. 
semakin dikukuhkan. Anak harus diajak untuk melihat dan mengalami hidup bersama yang baik dan menyenangkan. ${ }^{10}$

Secara teori padausia $0-8$ tahun pengalaman anak sangat berpengaruh dalam pembentukan karakater. Artinya di masa usia tersebut karakter anak masih dapat berubah-ubah tergantung dari pengalaman hidupnya. Oleh karena itu dalam membentuk karakter anak harus dimulai sedini mungkin bahkan sejak anak itu dilahirkan, karena berbagai pengalaman yang dilalui oleh anak semenjak perkembangan pertamanya, mempunyai pengaruh yang besar. Berbagai pengalaman ini sangat berpengaruh dalam mewujudkan apa yang dinamakan dengan pembentukan karakter diri secara utuh. Pembentukan karakter pada diri anak memerlukan suatu tahapan yang dirancang secara sistematis dan berkelanjutan. Sebagai individu yang sedang berkembang, setuiap anak memiliki sifat suka meniru tanpa mempertimbangkan baik atau buruk. Hal ini didorong oleh rasa ingin tahu dan ingin mencoba sesuatu yang diminati, yang kadang muncul secara spontan. Sikap jujur yang menunjukkan kepolosan seorang anak merupakan ciri yang juga dimiliki anak. Akhirnya sifat unik menunjukkan bahwa anak merupakan sosok individu yang kompleks yang memiliki perbedaan dengan individu lainnya. Menurut Arismantoro ${ }^{11}$

Sejatinya peran orang tuadalam pembentukan karakter anak itu sangat penting, karena orang tua yang mengajarkan anak berbahasadalam kehidupan sehari - hari. Banyak contoh yangdapat kita ambildari peran orang tua terhadap pembentukan karakter anak, seperti dalan keluarga da tradisi tidak membedakan hasil karya anak dengan antar saudara, dalam hal ini orang tualah yang sangat berperan karena dalam budaya ini hanya yang ada adalam keluarga tersebut yang bisa memahami. Peran keluarga adalah sebagai fondasi dalam pembentukan karakter anak sebagai landasan - landasan opembudayaan karakter melalui pembiasaan bersikap dan berperilaku yang sesuai dengan yang diharapkan. ${ }^{12}$

3. Pendidikan berbasis kecakapan hidup dan berkarakter islami

Pendidikan merupakan hak bagi setiap warga negara, karena itu setiap manusia yang itu lahir dan dibesarkan di Indonesia ini ia adalah warga Negara Indonesia yang berhak untuk mendapatkan pendidikan. Hak ini berlaku bagi siapa saja selama dia dianggap sah sebagai warga negara menurut undang-undang yang berlaku di Indonesia. Anak-anak yatim adalah salah satu dari warga negara yang berhak untuk mendapatkan pendidikan, mereka adalah warga Negara yang karena ayahnya meninggal sehingga seringkali mereka kurang mendapatkan pendidikan yang layak.jika anak yatim kita golongkan masuk ke dalam anak-anak yang terlantar, ketika kondisi ekonomi orangtuanya miskin maka ia termasuk fakir miskin, yang dalam hal ini menjadi tanggungjawab negara untuk memenuhi kebutuhan anak yatim.

Dalam bahasa inggris kecakapan hidup dapat disebut dengan life skil, yang memiliki makna are a set of human skill aquired via teaching or direct experience that are used to

\footnotetext{
${ }^{10}$ Sri Haryati, 'Pendidikan Karakter Dalam Kurikulum 2013'.

11 Sri Haryati.

${ }^{12}$ Hendarti Permono and M Psi, ‘Peran Orangtua Dalam Optimalisasi Tumbuh Kembang Anak Untuk Membangun Karakter Anak Usia Dini', Prosiding Seminar Nasional Parenting, 2013, 34-47, https://doi.org/10.1111/pce.12022.
} 
bandle problems and questions commonly encountered in daily buman life. Dalam istilah kecakapan hidup ini diartiakan sebagai seseorang yang memiliki kecakapan untuk mau dan berani dalammenghadapi broblem dalam kehidupan tanpa harus merasa tertekan, kemudian mencari jalan keluar dan mampu menyelesaikan masalahnya.

Sebenarnya pengertian dalam istilah kecakapan hidup ini sangatluas dibandingkan dengan sekedar sebagai keterampilan dalam bekerja. Indikaror indikator dalam kecakapan hidup ini dikelompookan menjadi 4, meliputi:

1. Kecakapan dalam mengenal diri atau self awarness atu yang biasakita sebut dengan kemampuan personal atau personal skills.

2. Kecakapan dalam bepikirrasional atau thingking skills atau juga kecakapan dalam akademik atau yang bisa kita sebut dengan akademik skills.

3. Kecakapan dalam sosial atau dalam bahasa inggris disebut social skills.

4. Kecakapan vokasional atau vocational skills atau yang bisakita sebut dengan keterampilan kejujuran dalam artian keterampilan yang diakaitka dengan suatu pekerjaan yang spesifik atau spesifik skills atau keterampilan teknis yang disebut juga dengan technical skills.

Jecques Delor mengatakan bahwa pada dasar dari program life skills ini berpegang pada empat pilar pembelajaran yang melipuiti:

1. Learning to know (belajar yang bertujuan untuk memperoleh pengetahuan).

2. Learning to do (belajar yang bertujuan untuk dapat berbuat suatu tindakan atau bekerja).

3. Learning to be (belajar yang bertujuaan untuk menjadi orang yang berguna).

4. Learning to live together (belajar yang bertujuan untuk dapat hidup bersama dengan orang lain atau bersosial). ${ }^{13}$

Dalam kecakapan hidup terdapat beberapa kecakapan dasar dan kecakapan instrumental. Dalam kecakapan dasar meliputi:

1. Kecakapan belajar mandiri.

2. Kecakapan dalam membaca, menulis dan menghitung.

3. kecakapan dalam berpikir ilmiah, kritis, nalar, rasional, lateral, sistem, kreatif, eksploratif, reasoning, pengambilan keputusan, dan pemecahan suatu masalah.

4. Kecakapan dalam berkomunikasih.

5. Kecakapan dalam kalbu atau dalam diri individu.

6. Kecakapan dalammengelolah raga.

7. Kecakapan dalam meumuskan atau membuat kepentingan dan upaya - upaya untuk mencapainya.

8. Kecakapan dalam berkeluarga dan bersosial.

Sedangkan dalam kecakapan intrumental meliputi bebrapa aspek yaitu:

1. Kecakapan dalammemanfaatkan teknologi.

2. Kecakapan dalam mengelolah sumberdaya, baik sumber daya alam maupun sumber daya manusia.

${ }^{13}$ Abdurrahman et al., 'PENDIDIKAN BERKARAKTER ISLAMI BAGI ANAK YATIM Oleh: Abdurrahman Misno Bambang Prawiro* Abstrak'. 
3. Kecakapan dalam kerjasamadengan baik, seperti gotong royong dan saling menolong.

4. Kecakapan dalam memanfaatkan informasih.

5. Kecakapan dalammenggunakan sistem.

6. Kecakapan dalam berwirausaha.

7. Kecakapan dalam kejujuran

8. kecakapan dalam memilih, menyiapkan, dan mengem - bangkan karir.

9. kecakapan dalam menjaga harmoni dengan lingkungan seperti menjaga lingkungan danmerawatnya.

10. Kecakapan dalam menyatukan bangsa.

5. Pendidikan anak usia dini sebagai bagian pendidikan nonformal

Ketika anak masih balita peran orang tua sebagai pendidik sangat dibutuhkan karena orang tua yang lebih dekat dengan anak, orang tua juga bisa dikatakan sebagai madrsah untuk anaknya, maka dari itu peran orang tua sangat penting. Ketika seorang anak ditinggal meninggal oleh ayahnya maka secepat mungkin harus ada peran ayah pengganti buat anak tersebut. Lingkungan juga termasuk pengaruh besar terhadap pendidikan anak.

Lingkungan yang mempunyai fungsi untuk melahirkan individu - individu terdidik (educational individuals) yang bisa dikatakan lingkungan pertama sebagai penunjang pendidikan karkter anak bukan hanya keluarga saja tapi juhga lingkungan sekolah merupakan hal pokok yang mendasari pendidikan karakter anak, tidak hanya itu lingkungan masyarakat juga termasuk halpenting. Pendidikan nonformal dapat dikatakan sebagai pelengkap dari pendidikan formal, terutama ketika dikaitkan dengan keterbatasan - keterbatasan yang diakibatkan oleh suatu hal. ${ }^{14}$

Ada tiga aspek lingkungan yang dapat mempengaruhi pendidkan karakter untuk anak, yaitu:

1. Lingkungan keluarga, keluarga sangat penting dalam proses pendidikan anakkarena mereka yang dapat memahmi apa yang diinginkan oleh anak.

2. Lingkungan sekolah, lingkungan sekolah ini sebagai wadah penunjang pendidikan anak yaitu sebagai pendidikan formal.

3. Lingkungan masyarakat,pergaulan adalah salah satu pengaruh yang mudah masuk pada karkter anak, ketika anak sudah nyaman dengan lingkungannya mereka akan menganggap teman adalah lebih dari keluarga ${ }^{15}$.

Adapun kemunculan dari pendidikan nonformal seperti lembanga pengasuh anak yatim, sebenarnya berfungsi sebagai pendidikan bagi anak - anak yang sejak kecil ditinngal meninggal oleh ayahnya. Dalam pantiasuhan ini anak

${ }^{14}$ I Ketut Sudarsana, 'Membentuk Karakter Anak Sebagai Generasi Penerus Bangsa Melalui Pendidikan Anak Usia Dini', Jurnal Purwadita 1, no. 1 (2017): 41-48.

${ }^{15}$ Jauhar Fuad, 'Pendidikan Karakter Dalam Pesantren Tasawuf', Jurnal Pemikiran Keislaman 23, no. 1 (2013); Hermino Agustinus, Manajemen Kurikulum Berbasis Karakter: Konsep, Pendekatan Dan Aplikasi (Bandung: Alfabeta, 2014). 
dapat merasakan kasih sayang dari orang tua angkatnya, orang tua angkatnya lah ayang akan membantu dalam perkembangan pendidikan berkarakter bagi dirinya saat dewasa nanti.

\section{Kesimpulan}

Pendidikan merupakan hak setiap warga Negara Indonesia, sehingga pemerintah harus menyediakan kesempatan seluas - luasnya kepada rakyatnya agar dapat memperoleh pendidikan yang berkualitas. Pada pembukaan UUD 1945 alinea 4 menyatakan bahwa Negara bertujuan mencerdaska kehidupan bangsa.

Selanjutnya diatur juga dalam pasal 31 ayat 1 UUD 1945 yang menyebutkan bahwa untuk mewujudkan tujuan tersebut, maka setiap warga Negara memiliki hak untuk mendapatkan pengajaran. Secara operasional, bentuk dukungan pendidikan yang terdapat dalam UU Nomor 20 tahun 2003 yang membahas tentang Sistem Pendidikan nasional pasal 5 yang menyatakan bahwa setiap warga Negara memiliki hak yang sama untuk memperoleh pendidikan yang bermutu.

Bila pendididkan diartikan sebagai latihan mental, moral, dan fisik yang bisa menghasilkan manusia berbudaya tinggi maka pendidikan berarti sebagai bahan untuk menumbuhkan personalitas (kepribadian) serta menanamkan rasa tanggungjawab. Usaha kependidikan bagi manusia itu menyerupai makanan yang berfungsi memberikan vitamin bagi proses pertumbuhan manusia. Ada beberapa anak yang wajib diberi wadah yang lebar untuk pendidikan, salah satunya yaitu anak yatim.

Anak yatim adalah anak yang sudah ditinggal mati oleh ayahnya sebelum dia baligh, dan batasan seorang anak dikatakan yatim adalah ketikadia sudah baligh dan dewasa. Didalam ajaran islam anak yatim mendapat perhatian khusus dibandingkan dengan anak - anak lainnya yang masih memeiliki kedua orang tua. Islam mengajarkan kita untuk memperhatikan mereka, berbuat baik kepada mereka mengurus dan mengasuh mereka serta menyayangi mereka. Islam juga begitu mengistimewakan mereka yang menjalankan perintah ini.

Ada beberapa bentuk tidak memuliahkan anak yatim diantaranya adalah dengan menyia nyiakan mereka sehingga menjadikan kehidupan mereka menjadi kekurang dan akhirnya menderita. Ada juga bentuk dalam menyia - nyiakan anak yatim yaitu dengan cara tidak memberikan mereka model pendidikan yang tidak sesuai apa karakter dan kebutuhan mereka, dan model yang digunakan dalam proses mendidiknya itu menjadikan suatu beban baginya.

Anak yatim ini sangat butuh yang namanya kasih sayang karena bisadikatakan mereka telah kehilang sosok yang menyayangi mereka, karena figur yang telah meninggalkan mereka sangat dibutuhkan dalam proses pembentukan karakter mereka.

Perkembangan karakter anak bangsa dapat dibentuk melalui karakter individu seseorng. Akan tetapi, karena manusia itu hidup sebagia makhluk sosial dan berbudaya, maka dalam pembentukan karakter individu dilakukan dalan lingkungan sosial dan budaya yang bersangkutan dengan linfkungan. Dapat diartikan pendidikan karakter manusia tidak pernah lepas dari lingkungn sosial, masyarakat, dan budaya bangsa.

Proses pembentukan karakter individu sangat penting dan sangat membutuhkan waktu yang sangat lama dan berlangsung seumur hidup. Apalagi karakter itu sendiri tidak dibawah oleh individu sejak lahir,akan tetapi dibentuk oleh pengalaman - pengalaman yang di dapat selama hidupnya, hal ini yang akan merubah karakter seseorang.

Pendidikan karakter sendiri sangat membutuhkan peran dari semua pihak, seperti orang tua, sekolah, lingkungan sekolah, dan masyarakat luas. Oleh karen itu tingkat keberhasilan dalam pembentukan karakter dapat dilihat atau dinilai dari kerjaama, keseimbangan dan keharmonisan 
semua aspek tersebut. Pendidikan karakter sendiri sangat penting dalam lingkungan keluarga, karena banyak orangtua yang menginginkan anaknya mempunyaikarakter yang baik.

Dari pembahasan mengenai pendidikan berkarakter Islami bagi anak yatim yang berbasis kecakapan hidup dapat disimpulkan sebagai berikut :

1. Dilihat dari psikologinya anak-anak yatim merasa kehilangan dengan meninggal- nya salah satu orang tua mereka yaitu ayah.

2. Kehilangan figur seorang ayah dalam kehidupan mengakibatkan mereka merasa kurang terlindungi sehingga kepribadian mereka cenderung lebih bebas.

3. Sangat diperlukan adanya model pendidikan yang tujuannya mengarahkan dan membimbing mereka untuk menjadi manusia yang mandiri baik pada saat proses pembelajarannya ataupun hasil dari pembelajaran tersebut.

4. Dalam pendidikan berkarakter Islami yang akan memberikan pola pembelajaran yang akan disesuaikan dengan tingkatan umur dan kematangan spiritual yang akan menjadi sesuatu yang harus ada bagi pendidikan mereka.

\section{Daftar Pustaka}

Abdurrahman, Oleh, Misno Bambang, Key Word Pendidikan, and Anak Yatim. 'PENDIDIKAN BERKARAKTER ISLAMI BAGI ANAK YATIM Oleh: Abdurrahman Misno Bambang Prawiro* Abstrak', 2009.

Abidin, Yunus. Desain Sistem Pembelajaran Dalam Konteks Kurikulum 2013. Cetakan kesatu. Bandung: Refika Aditama, 2014.

Agustinus, Hermino. Manajemen Kurikulum Berbasis Karakter: Konsep, Pendekatan Dan Aplikasi. Bandung: Alfabeta, 2014.

Fuad, Jauhar. 'Pendidikan Karakter Dalam Pesantren Tasawuf. Jurnal Pemikiran Keislaman 23, no. 1 (2013).

Ma`arif, Muhammad Anas. 'Analisis Strategi Pendidikan Karakter Melalui Hukuman Preventif. Ta'allum: Jurnal Pendidikan Islam 6, no. 1 (6 March 2018): 31-56. https://doi.org/10.21274/taalum.2018.6.1.31-56.

Ma`arif, Muhammad Anas, and Muhammad Husnur Rofiq. 'Pola Pengembangan Kurikulum Pendidikan Pesantren Berkarakter: Studi Pondok Pesantren Nurul Ummah Mojokerto’. TADRIS: Jurnal Pendidikan Islam 13, no. 1 (7 September 2018): 1-16. https://doi.org/10.19105/tjpi.v13i1.1635.

Nur Hakim, Muhammad, and Fitriyani Dwi Rahayu. 'Pembelajaran Saintifik Berbasis Pengembangan Karakter'. Nazhruna: Jurnal Pendidikan Islam 2, no. 1 (24 February 2019): 1-27. https://doi.org/10.31538/nzh.v2i1.148.

Permono, Hendarti, and M Psi. 'Peran Orangtua Dalam Optimalisasi Tumbuh Kembang Anak Untuk Membangun Karakter Anak Usia Dini’. Prosiding Seminar Nasional Parenting, 2013, 34-47. https://doi.org/10.1111/pce.12022.

prof. H.M. Arifin, M.Ed. Filsafat Pendidikan Islam. Edited by Fauzan Asy. PT Bumi Aksara, 2016.

Sri Haryati. 'Pendidikan Karakter Dalam Kurikulum 2013', 2013, 1-21.

Sudarsana, I Ketut. 'Membentuk Karakter Anak Sebagai Generasi Penerus Bangsa Melalui Pendidikan Anak Usia Dini'. Jurnal Purwadita 1, no. 1 (2017): 41-48.

Tafsir, Prof.Dr. ahmad. Metodologi Pengajaran Agama Islam. Edited by Mukhlis. bandung: PT Remaja Rosdakarya Offset, 2017. 